American Journal of Agricultural and Biological Sciences 5 (3): 282-285, 2010

ISSN 1557-4989

(C) 2010 Science Publications

\title{
DNA Polymorphism of Bovine Pituitary-Specific Transcription Factor and Leptin Gene Between Iranian Bos indicus and Bos taurus Cattle
}

\author{
${ }^{1}$ Arash Javanmard, ${ }^{2}$ Nader Asadzadeh and ${ }^{2}$ Fatollah Sarhadi \\ ${ }^{1}$ Department of Genomics, \\ West and North-West Agriculture Biotechnology Research Institute, Tabriz, Iran \\ ${ }^{2}$ Department of Biotechnology, Animal Science Research Institute, Karaj, Iran
}

\begin{abstract}
Problem statement: Variations at DNA level contribute to the genetic characterization of livestock populations and this may help to identify possible hybridization events as well as past evolutionary trends. Approach: The leptin and Pit-1 are attractive candidate genes for production and reproduction traits in cattle. A total of 247 Animals from four breeds from two species of Iranian cattle populations in include Bos taurus (Sarabi, Golpayegani) and Bos indicus (Sistani, Taleshi) were genotyped for the Pit-1 HinfI and leptin Sau3AI polymorphisms by the Polymerase Chain Reaction and Restriction Fragment Length Polymorphism (PCR-RFLP). Results: The genotype and gene frequencies for each group were determined and shown to be quite variable among the breeds. The allele B for the leptin gene and allele A for the Pit-1 gene were investigated high frequency in Bos indicus. Conclusion: Present result supported the previously proposed long evolutionary separation of these cattle subrace. Candidate gene approach may be a useful method to measure of genetic distance for cross breeding program between taurin and indicine cattle.
\end{abstract}

Key words: Pit-1, leptin, Bos taurus, Bos indicus, PCR-RFLP, polymorphism

\section{INTRODUCTION}

The assumption in animal breeding of genetic variation of quantitative traits caused by simultaneous segregation of many genes, each with small effect (so called infinitesimal model), is considered in animal breeding context very often. However it is doubtful that all gene influencing trait all have small effect and it is possible that a few genes may accountant for relatively large proportion of the genetic variation, these loci are known as Quantitative Traits Loci (QTL). Candidate genes are chose for study on basis known relationship in biochemical or physiological processes. Candidate gene approach may be a useful method to measure of genetic distance for cross breeding program between taurin and indicine cattle. Pit- 1 gene has been identified as the pituitary specific transcription factor that regulates the expression of the Growth Hormone (GH) and Prolactin (PRL) genes in the anterior pituitary (Tuggle et al., 1993). Renaville et al. (1997) showed that the $\mathrm{A}$ allele (especially the $\mathrm{AB}$ genotype) may have an effect on milk yield and its components. Leptin is a $16 \mathrm{KDa}$ proteins synthesized by adipose tissue (Itossner, 1998) and it is involved in the regulation of feed intake (Lagonigro et al., 2003), energy balance, fertility and immune function (Liefers et al., 2002). Leptin gene consists of three exons and two introns. Liefers et al. (2002) reported that heifers with the Sau3AI-AB genotype produce $1.32 \mathrm{~kg} \mathrm{day}^{-1}$ more milk and consume $0.73 \mathrm{~kg}$ day $^{-1}$ more food compared to those with the AA genotype. They also suggested that the B allele may have a role in improving milk production without negative energy balance and low fertility. Buchanan et al. (2003) reported that the T allele of the bovine leptin gene resulted in the production of more milk and higher somatic cell count but did not have a significant effect on milk fat or protein during lactation. Lagonigro et al. (2003) reported an association between five single nucleotide polymorphisms within the leptin gene and feed intake as well as fat traits. Almeida et al. (2003) found two alleles responsible for increasing the calving interval, thus, they suggested selection against these carriers could improve calving interval at least 2 months. The main objective of the present investigation was to comparison of genetic variations in the Pit-1 and leptin gene of the two Iranian Bos indicus, Bos taurus cattle.

Corresponding Author: Arash Javanmard, Department of Genomics,

West and North-West Agriculture Biotechnology Research Institute, Tabriz, Iran 


\section{MATERIALS AND METHODS}

Experimental material: A total of 247 of Bos taurus cattle (Sarabi, $\mathrm{n}=82$ and Golpayegani, $\mathrm{n}=57$ ) and Bos indicus cattle (Sistani $\mathrm{n}=38$ and Taleshi, $\mathrm{n}=70$ ) were used in this study. The populations were located at the Shabestar, Sarab, Delijan, Golpayegan, Zehak, Talash and Mazandaran Jahad-e-Keshavarzi animal breeding stations.

DNA extraction: DNA was extracted from blood samples from each animal using the method of Boom et al. (1989). To an aliquot of $100 \mu \mathrm{L}$ thawed blood, $400 \mu \mathrm{L}$ of lysis buffer (Guanidin Thiocyanate, $20 \mathrm{mM}$; EDTA, $20 \mathrm{mM}$; Tris- $\mathrm{HCl}, 10 \mathrm{mM}$; Triton $\mathrm{X}_{100}, 40 \mathrm{~g} \mathrm{~L}^{-1}$; DTT, $10 \mathrm{~g} \mathrm{~L}^{-1}$ ) was added, the mixture was vortexed and incubated at $65^{\circ} \mathrm{C}$ for $5 \mathrm{~min}$. The cells were resuspended in $20 \mu \mathrm{L}$ of nuclease solution (4 g Silica gel, $100 \mathrm{~mL}$ Guanidine solution) and spun for $10 \mathrm{sec}$ at $12,000 \times \mathrm{g}$. The pellet was resuspended in $200 \mu \mathrm{L}$ of lysis buffer. The white blood cell suspension was then added to $400 \mu \mathrm{L}$ of saline buffer $(1 \mathrm{M} \mathrm{NaCl}, 10 \mathrm{mM}$ Tris-HCL, $1 \mathrm{M} \mathrm{KCl}$ and $20 \mathrm{mM}$ EDTA), the mixture was vortexed and then spun for $10 \mathrm{sec}$ at $5,000 \times \mathrm{g}$. The DNA was precipitated with $45-$ $55 \mu \mathrm{L}$ of extra gene solution (10\% Ion Exchange Resin:, $0.02 \%$ Orange $\mathrm{G}$ color, $0.01 \%$ Triton $\mathrm{X}_{100}$ ) and then incubated at $65^{\circ} \mathrm{C}$ for 3-5 min. Protein was then precipitated by centrifugation ( $3 \mathrm{~min}$ at $1000 \times \mathrm{g}$ ) and the upper layer containing the DNA was transferred to another tube. Relative purity of the DNA was determined using a spectrophotometer based on absorbances at 260 and $280 \mathrm{~nm}$.

PCR-RFLP analysis: The sequences of the forward and reverse primers for the amplification of the Pit-1 gene were:

\section{Pit1F 5'-GAGCCTACATGAGACAAGCATC-3' Pit1R 5'-AAATGTACAATGTGCCTTCTGA-3'}

The polymerase chain reaction for the Pit- 1 gene pair primers was performed in $25 \mu \mathrm{L}$ reaction mixtures containing $1.5 \mathrm{mM} \mathrm{MgCl}, 200 \mu \mathrm{M}$ of each dNTPs, $0.3 \mu \mathrm{M}$ of each primers, $1 \mathrm{X}$ PCR buffer, $1 \mathrm{U}$ Taq polymerase (Cinagen, Iran) and $100 \mathrm{ng}$ of genomic DNA template. The DNA thermal cycler (Perkin Elmer 9700). Thermal cycling conditions included: An initial denaturation step at $95^{\circ} \mathrm{C}$ for $2 \mathrm{~min}$, followed by 30 cycles of $95^{\circ} \mathrm{C}$ for $45 \mathrm{Sec}, 60^{\circ} \mathrm{C}$ for $1 \mathrm{~min}$ and $72^{\circ} \mathrm{C}$ for $1 \mathrm{~min}$ and a final extension at $72^{\circ} \mathrm{C}$ for $3 \mathrm{~min}$. The PCR products were digested with
$10 \mathrm{U}$ of HinfI (Gibco BRL, life Technologies, USA) at $37^{\circ} \mathrm{C}$ for at least $14 \mathrm{~h}$.

One part of second intron of leptin gene was amplified using the following primers:

LepF: 5'-TGGAGTGGCTTGTTATTTTCTTCT-3' LepR: 5'-GTCCCCGCTTCTGGCTACCTAACT-3'

PCR reaction was performed using $0.5 \mathrm{U}$ Taq polymerase and $50 \mathrm{ng}$ of DNA. Thermal cycling conditions were as follows: initial denaturation at $94^{\circ} \mathrm{C}$ for $2 \mathrm{~min}$, followed by 35 cycles of $94^{\circ} \mathrm{C}, 55^{\circ} \mathrm{C}$ and $72^{\circ} \mathrm{C}$ (each for $1 \mathrm{~min}$ ) and a final extension at $72^{\circ} \mathrm{C}$ for $15 \mathrm{~min}$. The PCR products were digested overnight at $37^{\circ} \mathrm{C}$ with $10 \mathrm{U}$ of Sau3AI (Roche, Germany). The Restriction fragments from the above PCR reactions were electrophoresed on $2 \%$ agarose gels and stained with ethidium bromide.

Statistical analysis: The data was alaysed using the POPGENE software version 1.31 (Yeh et al., 1999).

\section{RESULTS}

There was one polymorphic HinfI site in the $600 \mathrm{bp}$ PCR product within exon 6 of Pit- 1 gene. The digested PCR product exhibited one fragment of $600 \mathrm{bp}$ for AA genotype and for the BB genotype, the $600 \mathrm{bp}$ fragment was two fragments of 357 and $243 \mathrm{bp}$. Figure 1 shows the restriction pattern of three genotypes $\mathrm{AA}, \mathrm{AB}$ and $\mathrm{BB}$ upon digestion of Pit-1 HinfI. The $442 \mathrm{bp}$ fragment of the leptin gene also contained two restriction sites of Sau3AI. The AB PCR product was three fragments of 303, 88 and 32 bp (bands not detected on the gel). Sequence analysis of Sau3AI site in the leptin gene revealed a mutation at position 1180 that was a $\mathrm{C}$ to $\mathrm{T}$ transition. Figure 2 shows the restriction pattern of the three genotypes of the leptin gene. Allele and genotype frequencies and the average heterozygosity (Nei, 1978) in four Iranian cattle populations for the Pit-1 and leptin loci were resulted (Table 1). Although the B allele is favorable for the leptin gene (Almeida et al., 2003; Pomp et al., 1997) and A allele for the Pit-1 gene (Sabour et al., 1996), AB genotype is preferred by both the candidate genes (Almeida et al., 2003; Pomp et al., 1997; Renaville et al., 1997; Woollard et al., 1994). The highest $\mathrm{B}$ allele frequency for the leptin gene (0.875) and A allele for the Pit-1 genes were estimated in Sistani cattle. However, the highest AB genotype frequency was found in Taleshi and Sarabi for the leptin and Pit-1 genes, respectively. 
Table 1: Distribution of Leptin and Pit-1 genotype and allele frequencies in Iranian (Sarabi, $\mathrm{n}=82$ and Golpayegani, $\mathrm{n}=57$ ) and Bos indicus cattle (Sistani $\mathrm{n}=38$ and Taleshi, $\mathrm{n}=70$ )

\begin{tabular}{|c|c|c|c|c|c|c|c|c|c|c|c|}
\hline \multirow[b]{3}{*}{ Population } & \multicolumn{6}{|c|}{ Leptin gene } & \multicolumn{5}{|c|}{ Pit-1 gene } \\
\hline & \multirow{2}{*}{$\begin{array}{l}\text { No. } \\
\text { sample }\end{array}$} & \multicolumn{3}{|c|}{ Genotype frequency } & \multicolumn{2}{|c|}{ Allele frequency } & \multicolumn{3}{|c|}{ Genotype frequency } & \multicolumn{2}{|c|}{ Allele frequency } \\
\hline & & AA & $\mathrm{AB}$ & BB & A & B & AA & $\mathrm{AB}$ & BB & A & B \\
\hline Sarabi & 82 & 0.561 & 0.378 & 0.061 & 0.75 & 0.25 & 0.451 & 0.341 & 0.207 & 0.62 & 0.38 \\
\hline Golpayegani & 57 & 0.544 & 0.351 & 0.105 & 0.72 & 0.28 & 0.614 & 0.263 & 0.123 & 0.75 & 0.25 \\
\hline Sistani & 38 & 0.211 & 0.263 & 0.526 & 0.35 & 0.65 & 0.842 & 0.158 & 0.000 & 0.92 & 0.78 \\
\hline Taleshi & 70 & 0.100 & 0.757 & 0.143 & 0.47 & 0.53 & 0.614 & 0.314 & 0.071 & 0.77 & 0.23 \\
\hline
\end{tabular}

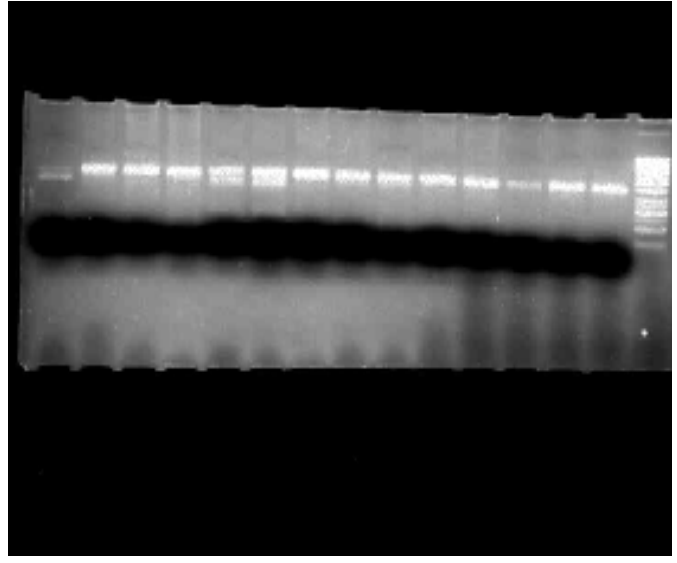

Fig. 1: Sau3AI and HinfI polymorphism at bovine Leptin (A)

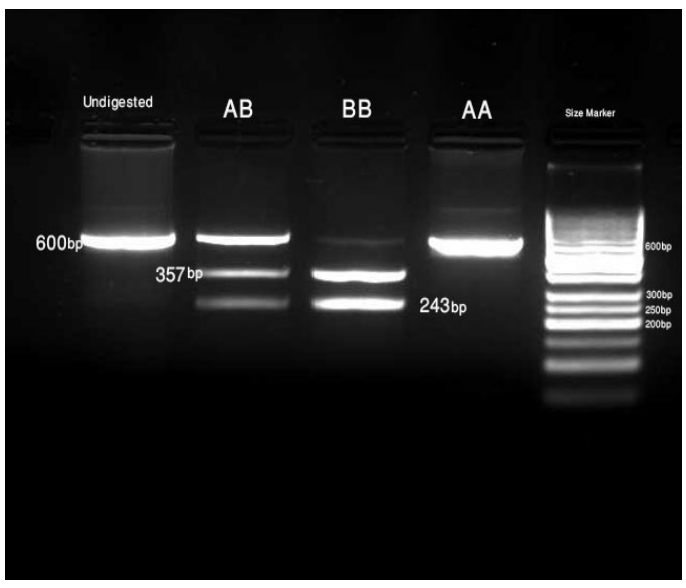

Fig. 2: The Pit-1(B) genes. Electrophoretic patterns of three genotypes separated on $2 \%$ agarose gel for each gene. Molecular weight of marker is SM037 from Fermentas (SM037 from MB1 fragments)

\section{DISCUSSION}

A main goal of the animal breeder is to select superior animals for breeding. Screening favorable alleles for selection at the DNA level provides an ideal tool for marker-assisted selection. RFLP polymorphism within the bovine Pit-1 gene was first detected with HinfI nuclease by (Woollard et al., 1994). Sabour et al. (1996) showed that allele A in Pit-1 locus positively affected milk production traits in Friesian cattle. This allele (frequency of 0.18) showed a significant superiority over allele B for milk and milk protein yields and body conformation traits within Italian Holstein Friesian cattle.

The allele and genotype frequencies are variable among different studied populations and also the favorable allele and genotype frequencies in world cattle populations. The Pit-1 A allele frequencies have been estimated to be 0.45 in Angus; 0.26 in Holstein; 0.21 in Herford; 0.28 in Gelbvieh; 0.1 in Brahman; 0.25 in Polish and 0.95 in Gry cattle (Zwierzchowski et al., 2001). Pomp et al. (1997) have reported leptin B allele frequencies of 0.3 in Limousine; 0.21 in Simmental; 0.28 in Gelbvieh; 0.29 in Holstein; 0.5 in Hereford, 0.27 in Angus, 1.0 in Brahman and 0.4 in Branguse. Therefore, breeding strategies could be designed for introregression of the A allele for Pit-1 and B allele for leptin from Iranian Bos indicuse and Bos taurus. Therefore, it is suggested that crossbreeding should be done between these populations and/or with exotic breeds to increase the frequency of the favorable genotype.

\section{CONCLUSION}

In conclusion, the possible association between molecular polymorphisms within these candidate genes and economic traits for the studied populations should be further investigated.

\section{ACKNOWLEDGMENT}

We thank Dr. Ilias Kappas from Thessaloniki University, Greece for their excellent comments on our manuscript. We also thank the Iranian cattle breeding stations for their collaboration in sampling procedure. This research was completely funded by East 
Azarbyjan Management and Programming Center for Scientific Research and Technology Application.

\section{REFERENCES}

Almeida, S.E., J.C.F. Moraes and T. Weimar, 2003. Molecular marker in the LEP gene and reproductive performance of beef cattle. Anim. Genet. Breed., 120: 106-113.

Boom, R., C.J.A. Sol, M.M.M. Salimans, C.L. Jansen, P.M.E. Wertheim-Van Dillen and J. van der Noordaa, 1989. Rapid and simple method for purification of nucleic acids. J. Clin. Microbiol., 28: 495-503.

Buchanan, F.C., A.G. Vans Kessel, C. Waldner and D.A. Christensen et al., 2003. An Association between a leptin single nucleotide polymorphism and milk and protein yield. J. Dairy Sci., 86: 3164-3166.

Itossner, K.L., 1998. Cellular, molecular and physiological aspects of leptin: Potential application in animal production. Can. J. Anim. Sci., 26: 463-480.

Lagonigro, R., P. Wiener, F. Pilla, J.A. Woolliams and J. William, 2003. A new mutation in the coding region of the bovine leptin gene associated with feed intake. Anim. Genet., 34: 371-374 .

Liefers, S.C., R.F. Veerkamp and T. Vanderlene, 2002. Association between leptin gene polymorphism and production, live weight, energy balance, feed intake and fertility in Holstein heifers. J. Dairy Sci., 85: 1633-1638.

Nei, M., 1978. Estimation of average heterozygosity and genetic distance from a small number of individuals. Genetics, 89: 583-590 .
Pomp, D., T. Zou, A.C. Clutter and W. Barendse, 1997. Mapping of leptin to Bovine chromosome 4 by linkage analysis of a PCR-based polymorphism. J. Anim. Sci., 75: 1427.

Renaville, R., N. Gengleer, E. Vrech, A. Prandi and S. Massart et al., 1997. Pit-1 gene polymorphism, milk yield and conformation traits for Italian Holstein-Friesian bulls. J. Dairy Sci., 80: 3431-3438.

Sabour, M.P., C.Y. Lin, A.J. Lee and A.J. Mcallister, 1996. Association between milk protein variation and genetic value of Canadian Holstein bulls for milk yield traits. J. Dairy Sci., 79: 1050-1056.

Tuggle, C.K., T.P. Yu, J. Helm and M.F. Rothschild, 1993. Cloning and restriction fragment length polymorphism analysis of a cDNA for swine Pit-1 gene controlling growth hormone expression. Anim. Genet., 24: 17-21.

Woollard, J., C.B. Schmitz, A.E. Freeman and C.K. Tuggle, 1994. HinfI polymorphism at the bovine Pit-1 locus. J. Anim. Sci., 72: 3267.

Yeh, F.C., R. Yang and T. Boyle, 1999. POPGENE Version 1.31. Microsoft Window-Based Free Software for Population Genetic Analysis. University of Alberta, Edmonton, AB, Canada.

Zwierzchowski, L., J. Oprzadek, E. Dymnicki and P. Dzierzbicki, 2001. An association of growth hormone, kappa-casein, beta-lactoglobulin, leptin and Pit-1 loci polymorphism with growth rate and carcass traits in beef cattle. Anim. Sci. Papers Rep., 19: 65-77. 